\title{
Utilization of nitrate stable isotopes of Chydorus sphaericus (OF Müller) to elucidate the hydrological characteristics of riverine wetlands in the Nakdong River, South Korea
}

\author{
Jong-Yun $\mathrm{CHOI}^{1^{*}}$ (D), Seong-Ki KIM${ }^{1}$, Jeong-Cheol KIM¹ and Geung-Hwan LA²
}

\begin{abstract}
Background: This study aimed to identify $\mathrm{NO}_{3}{ }^{-} \mathrm{N}$ sources using the stable isotope $\delta^{15} \mathrm{~N}$ in Chydorus sphaericus (OF Müller), to investigate hydrological characteristics and nutrient states in artificial wetlands near the Nakdong River. Chydorus sphaericus is dominant in wetlands where aquatic plants are abundant, occurring in high density, and is sensitive to wetland water pollution, making it suitable for identification of $\mathrm{NO}_{3}{ }^{-}-\mathrm{N}$ sources.

Results: $\mathrm{NO}_{3}{ }^{-}-\mathrm{N}$ sources for each wetland were strongly dependent on hydrological characteristics. Wetlands with sewage or rainfall/groundwater as their main sources had high levels of $\mathrm{NO}_{3}{ }^{-}-\mathrm{N}$, whereas wetlands with surface water as their main input had comparatively lower levels. Since wetlands with sewage and rainfall/groundwater as their main water sources were mostly detention ponds, their inputs from tributaries or the main river stream were limited and nutrients such as $\mathrm{NO}_{3}{ }^{-}-\mathrm{N}$ easily become concentrated. Changes in $\mathrm{NO}_{3}{ }^{-}-\mathrm{N}$ levels at each wetland were closely associated with $\delta^{15} \mathrm{~N}$ of $\mathrm{C}$. sphaericus. Interestingly, regression analysis also showed positive correlation between $\delta^{15} \mathrm{~N}$ of $\mathrm{C}$. sphaericus and $\mathrm{NO}_{3}{ }^{-}-\mathrm{N}$ level.

Conclusions: We conclude that the nitrate stable isotope $\left(\delta^{15} \mathrm{~N}\right)$ of $C$. sphaericus can be used to elucidate the hydrological characteristics of riverine wetlands. This information is important for maintenance and conservation of artificial wetlands at the Nakdong River.
\end{abstract}

Keywords: Hydrological characteristics, Indicator species, Stable isotope analysis, Water pollution, Four Rivers Project, Nitrate contamination

\section{Background}

Nitrate contamination is a pervasive problem in various areas associated with agricultural fields, including the South Korean riverine wetlands (Kellman and HillaireMarcel 2003; Kim et al. 2015). Such contamination is especially concerning in tile-drained areas since large amounts of $\mathrm{NO}_{3}{ }^{-} \mathrm{N}$ in water can be discharged rapidly into wetlands (Kovacic et al. 2000; Green and Galatowitsch 2001, 2002). Agricultural use of both inorganic N

\footnotetext{
* Correspondence: jyc311@nie.re.kr

${ }^{1}$ National Institute of Ecology, Seo-Cheon Gun, Chungcheongnam Province 33657, South Korea

Full list of author information is available at the end of the article
}

fertilizers and various animal waste fertilizers complicates the evaluation of various $\mathrm{N}$ fertilizer application types. Riverine wetlands and surrounding areas of inflow streams in South Korea consist mostly of agricultural lands and orchards from which there is an inflow of a diverse array of potential contaminants. In areas with multiple potential sources of contamination, measurement of their relative contributions may help to clarify the contamination processes.

Empirical studies suggest that stable nitrate isotopes can be used to discriminate between the sources of $\mathrm{NO}_{3}{ }^{-}-\mathrm{N}$ in field settings because $\mathrm{NO}_{3}{ }^{-}-\mathrm{N}$ compounds from different sources have characteristic isotopic ratios

(c) The Author(s). 2019 Open Access This article is distributed under the terms of the Creative Commons Attribution 4.0 International License (http://creativecommons.org/licenses/by/4.0/), which permits unrestricted use, distribution, and reproduction in any medium, provided you give appropriate credit to the original author(s) and the source, provide a link to the Creative Commons license, and indicate if changes were made. The Creative Commons Public Domain Dedication waiver (http://creativecommons.org/publicdomain/zero/1.0/) applies to the data made available in this article, unless otherwise stated. 
(Kellman and Hillaire-Marcel 2003; Lee et al. 2008). During the mineralization of dissolved organic $\mathrm{N}$, nitrate stable isotopes are the same as those of the original organic $\mathrm{N}$ in the +4 to $+9 \%$ range (Heaton 1986). The distinct differences in the nitrate stable isotopes means that $\mathrm{NO}_{3}{ }^{-}-\mathrm{N}$ in waters originating from a combination of sources should be represented within the range of these samples if $\mathrm{NO}_{3}{ }^{-} \mathrm{N}$ behaves in a conservative manner during transport (Heaton 1986). This understanding has been the basis for the identification of $\mathrm{NO}_{3}{ }^{-} \mathrm{N}$ sources using natural abundances of $\delta^{15} \mathrm{~N}$ during studies on nitrate contamination (Wells and Krothe 1989). Normally, the stable isotopic value of $\mathrm{NO}_{3}{ }^{-}-\mathrm{N}$ can be obtained from oxidizable carbon sources such as dissolved organic carbon (DOC). However, it is necessary to filter a large volume of water to prepare a sample for nitrate stable isotope measurement from DOC, and because wetlands have strong habitat heterogeneity as a standing environment, water must be collected at multiple points to achieve a representative measurement. Therefore, it is difficult not only to measure the nitrate stable isotopes that represent wetlands, but also to trace the changes in nitrogen sources.

Chydorus sphaericus (OF Müller) has a wide distribution range (Illyová and Némethová 2005), is highly sensitive to environmental changes such as water pollution, and continuously uses phytoplankton as a food source; therefore, the nitrate stable isotopes of this species are suitable for the identification of $\mathrm{NO}_{3}{ }^{-}-\mathrm{N}$ sources in wetlands. Chydorus sphaericus is often attributed to littoral areas where macrophytes are abundant (Ali et al. 2007; Choi et al. 2015), therefore, this species is probably better adapted to detrital food sources compared to largebodied pelagic cladocerans (e.g., representatives of the Bosmina genus; Vijverberg and Boersma 1997). Chydorus sphaericus is very tolerant, not only to chemical changes such as dissolved oxygen, $\mathrm{pH}$, and water temperature, but also to trophic level changes (Rybak and Błędzki 2010). Tavernini (2008) stated that a smallbodied zooplankton, such as $C$. sphaericus, is influenced by the level of eutrophication. Therefore, C. sphaericus is often considered to be an indicator species for the eutrophication of lakes in temperate climates (Kattel and Sirocko 2011).

Small water bodies can have different origins, which may reflect the age of the wetland or the characteristics of the bottom sediments, which in turn may directly influence a variety of physical and chemical features of the water and indirectly influence the in vivo formation (e.g., assimilation material) for the inhabiting organisms. Moreover, the characteristics of the catchment area of wetlands (e.g., anthropogenically modified, inflow of pollutants from tributaries) may also be of great importance in influencing the water quality and consequently the structure of the inhabiting plant and animal communities (Wantzen and Junk 2000).

This study aimed to compare the nitrate stable isotopes of C. sphaericus among different types of riverine wetlands, representing different inflow channels of nitrogen source. Chydorus sphaericus has been hypothesized to be a very good indicator species, not only for trophic conditions and changes in pollutants in the aquatic environment, but also to reflect other environmental features such as the level of habitat heterogeneity, different types of catchment areas of a water body, and the various morphometric features of a wetland. We predicted that different concentrations of $\mathrm{NO}_{3}{ }^{-}-\mathrm{N}$ in each wetland would be clearly related to $\delta^{15} \mathrm{~N}$ in C. sphaericus.

\section{Results and discussion}

Influence of chemical factors on hydrological characteristics

The forms and hydrological characteristics of artificial wetlands along the Nakdong River were diverse without being one-sided (Fig. 1; Table 1). Channel type formations, in the form of small streams, occurred most frequently. In the upper and lower parts of these wetlands, inlets and outlets supported efficient water conveyance due to their connection with the main river and tributaries, with riparian connectivity evaluated as being "good". Detention ponds, with water supplied by sewage, rainfall, and groundwater, rather than by surface water, often showed poor riparian connectivity. Riparian type wetlands located in the channel of the main river were supplied mainly by the river itself, with excellent riparian connectivity, but evaluated as "good" in this study. The soil type and topography of most study sites were found to be regosol and floodplain, respectively, with similarities due to their construction and subsequent flooding influence. Exceptions included wetlands 2 and 12, which represented a water channel (found within an existing stream) and an island, respectively.

The chemical factor largely depended on the hydrological characteristics of each wetland (Fig. 2). The highest levels of $\mathrm{NO}_{3}{ }^{-}-\mathrm{N}$ were found in wetlands fed by sewage sources, with similar results found across spring and autumn. The sewage inflows occur from agricultural land and residential areas rather than from tributaries or the main river. Previous studies have suggested that wetlands or streams influenced by agricultural land or animal farming are prone to eutrophication or water pollution (Euliss and Mushet 1999; Woli et al. 2002). Wetlands with rainfall/groundwater sources had similarly high $\mathrm{NO}_{3}{ }^{-}-\mathrm{N}$ levels. These wetlands generally had poor inlet and outlet functions and low water conveyance efficiency, which makes them highly prone to $\mathrm{NO}_{3}{ }^{-}-\mathrm{N}$ enrichment. Meanwhile, wetlands supplied by 

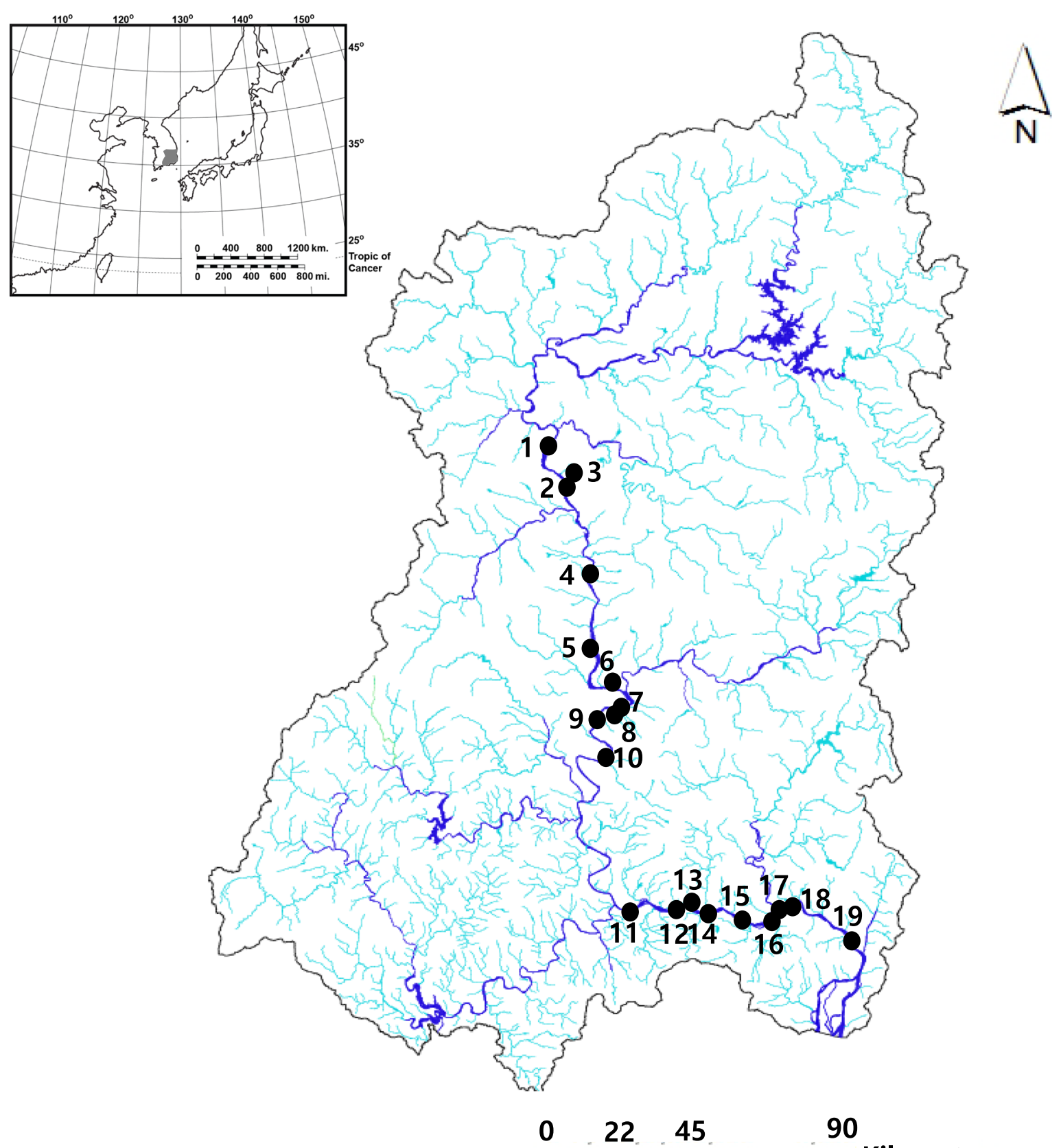

90

Fig. 1 Study sites located along the Nakdong River, indicated by solid circles

•). The small map in the upper left corner indicates the Korean Peninsula

surface water had lower $\mathrm{NO}_{3}{ }^{-} \mathrm{N}$, due to greater flow efficiency precluding its local concentration.

Riparian connectivity categorizations, i.e., as good, moderate, or poor, showed similar characteristics. Wetlands with poor riparian connectivity mostly consisted of detention ponds with little input from tributaries or the main river. As a result, nutrients such as $\mathrm{NO}_{3}{ }^{-}-\mathrm{N}$ may become enriched to high concentrations. In contrast, wetlands with excellent riparian connectivity, such as channels and riparian types, have robust interactions with the main river or tributaries, and thus minimal $\mathrm{NO}_{3}{ }^{-}-\mathrm{N}$ enrichment. However, some channel type wetlands were assessed to have moderate riparian connectivity but had high $\mathrm{NO}_{3}{ }^{-} \mathrm{N}$ levels. These wetlands formerly had good inlet and outlet 
Table 1 Local-scale hydrological characteristics in each studied wetland in the Nakdong River basin

\begin{tabular}{|c|c|c|c|c|c|c|c|c|c|c|c|}
\hline Num. & Type & $\begin{array}{l}\text { Water } \\
\text { source }\end{array}$ & $\begin{array}{l}\text { Riparian } \\
\text { connectivity }\end{array}$ & Soil type & Topography & $\begin{array}{l}\text { Edge } \\
\text { index }\end{array}$ & Area $\left(m^{2}\right)$ & $\begin{array}{l}\mathrm{NO}_{3}{ }^{-}-\mathrm{N} \\
\text { (spring) }\end{array}$ & $\begin{array}{l}\mathrm{NO}_{3}{ }^{-}-\mathrm{N} \\
\text { (autumn) }\end{array}$ & $\begin{array}{l}\text { Chydorus } \\
\text { sphaericus } \\
\text { (spring) }\end{array}$ & $\begin{array}{l}\text { Chydorus } \\
\text { sphaericus } \\
\text { (autumn) }\end{array}$ \\
\hline 1 & Channel & Surface water & Good & Regosol & Flood plain & 0.035 & 44,083 & 4.8 & 5.2 & 4.7 & 6.6 \\
\hline 2 & Detention pond & Sewage & Poor & Regosol & Water channel & 0.018 & 8347 & 10.6 & 8.3 & 6.7 & 8.4 \\
\hline 3 & Riparian & Surface water & Good & Regosol & Flood plain & 0.025 & 87,000 & 3.2 & 4.5 & 4.2 & 5.9 \\
\hline 4 & Detention pond & Rainfall/groundwater & Poor & Regosol & Flood plain & 0.041 & 22,590 & 7.0 & 8.5 & 6.1 & 7.7 \\
\hline 5 & Channel & Surface water & Good & Regosol & Flood plain & 0.036 & 10,400 & 5.4 & 6.4 & 6.1 & 7.1 \\
\hline 6 & Detention pond & Rainfall/groundwater & Poor & Regosol & Flood plain & 0.029 & 4630 & 7.6 & 8.6 & 7.4 & 7.8 \\
\hline 7 & Riparian & Surface water & Good & Regosol & Flood plain & 0.015 & 15,000 & 3.3 & 4.7 & 3.9 & 5.6 \\
\hline 8 & Riparian & Surface water & Good & Regosol & Flood plain & 0.018 & 24,168 & 4.1 & 5.0 & 4.3 & 6.2 \\
\hline 9 & Channel & Sewage & Moderate & Regosol & Flood plain & 0.027 & 38,628 & 11.8 & 12.5 & 7.6 & 8.3 \\
\hline 10 & Riparian & Surface water & Good & Regosol & Flood plain & 0.019 & 75,000 & 3.8 & 4.3 & 3.8 & 6.0 \\
\hline 11 & Channel & Surface water & Good & Regosol & Flood plain & 0.035 & 390,000 & 5.2 & 5.9 & 5.1 & 6.7 \\
\hline 12 & Detention pond & Sewage & Moderate & Regosol & Island & 0.011 & 60,456 & 9.5 & 7.8 & 7.3 & 8.0 \\
\hline 13 & Channel & Surface water & Good & Regosol & Flood plain & 0.029 & 426,551 & 5.8 & 6.2 & 6.8 & 7.2 \\
\hline 14 & Channel & Surface water & Good & Regosol & Flood plain & 0.064 & 17,500 & 6.4 & 7.3 & 6.7 & 6.8 \\
\hline 15 & Channel & Surface water & Moderate & Regosol & Flood plain & 0.021 & 122,000 & 5.2 & 5.9 & 5.1 & 6.7 \\
\hline 16 & Detention pond & Rainfall/groundwater & Poor & Regosol & Flood plain & 0.068 & 33,700 & 9.8 & 8.5 & 7.6 & 7.6 \\
\hline 17 & Channel & Surface water & Good & Regosol & Flood plain & 0.018 & 147,400 & 6.8 & 7.9 & 6.8 & 7.6 \\
\hline 18 & Channel & Sewage & Moderate & Regosol & Flood plain & 0.021 & 68,579 & 11.5 & 11.6 & 7.8 & 8.6 \\
\hline 19 & Riparian & Surface water & Good & Regosol & Flood plain & 0.031 & 34,024 & 4.1 & 5 & 4.3 & 6.2 \\
\hline
\end{tabular}

functions and interaction with the main river at the time of construction, but these functions had diminished due to the sedimentation of soil and plant remains. In the future, these wetlands are likely to develop into detention ponds whose water source is supplied by rainfall/groundwater rather than by the main river. Therefore, active management is required to maintain the function of wetlands corresponding to their construction purpose.

\section{Relationship between $\delta^{15} \mathrm{~N}(\%)$ of Chydorus sphaericus and $\mathrm{NO}_{3}{ }^{-} \mathrm{N}$}

$\mathrm{NO}_{3}{ }^{-}-\mathrm{N}$ levels measured in each wetland were closely related to $\delta^{15} \mathrm{~N}$ in C. sphaericus (Figs. 2 and 3). Differing levels of $\mathrm{NO}_{3}{ }^{-}-\mathrm{N}$ according to the water source and riparian connectivity also showed a similar pattern with $\delta^{15} \mathrm{~N}$ in C. sphaericus. This signified that the $\mathrm{NO}_{3}{ }^{-}-\mathrm{N}$ level of each wetland could be indicated by $C$. sphaericus. In general, the $\delta^{15} \mathrm{~N}$ ratio allows the discrimination of trophic levels and can provide information about the processing of nitrogen and its sources (Peterson and Fry 1987). In freshwater ecosystems, biological communities accumulate pollutants relatively easily via the food web and show a nitrate stable isotope ratio that is highly correlated with pollutants, such as organohalogen compounds (Kidd et al. 1998; Power et al. 2002). Swanson et al. (2003) suggested that the higher the trophic levels of the food chain, the higher the bodily concentrations of nitrate- related pollutants. Anthropogenic pollutants generally have heavy nitrate stable isotopes compared to organic matter that is produced naturally (Lake et al. 2001), and the $\delta^{15} \mathrm{~N}$ levels in animals influenced by these pollutants tend to be high (Wayland and Hobson 2001; Lee et al. 2013). Nutrients often enter surface waters from diffuse or non-point sources associated with surface runoff and from point sources typically associated with intensive farming activities (Knight et al. 2000). Microcrustaceans that use phytoplankton as their major food source, including cladocerans or copepods, reflect changes in the nitrate stable isotope ratio of outer-origin organic materials within the habitat (Cole et al. 2011), leading to a close link with anthropogenic pollutants (Alcorlo and Baltanás 2013). In the present study, high levels of $\mathrm{NO}_{3}{ }^{-}-\mathrm{N}$ in water and $\delta^{15} \mathrm{~N}$ of C. sphaericus were mainly observed in wetlands with poor riparian connectivity and sewage sources. Phytoplankton, which naturally accrue non-point source pollution, serve as the main food source of $C$. sphaericus (i.e., as primary consumers), which, therefore, enables a sensitive response to such pollution. Regression analyses in the present study also indicated a positive correlation between $\delta^{15} \mathrm{~N}$ of $C$. sphaericus and $\mathrm{NO}_{3}{ }^{-}-\mathrm{N}$ levels (Fig. 3).

However, the changes in $\delta^{15} \mathrm{~N}$ levels in C. sphaericus in response to the nitrate levels in water do not occur in a short period of time. The $\delta^{15} \mathrm{~N}$ of $C$. sphaericus was not found to be sensitive to periodic changes in nitrate 

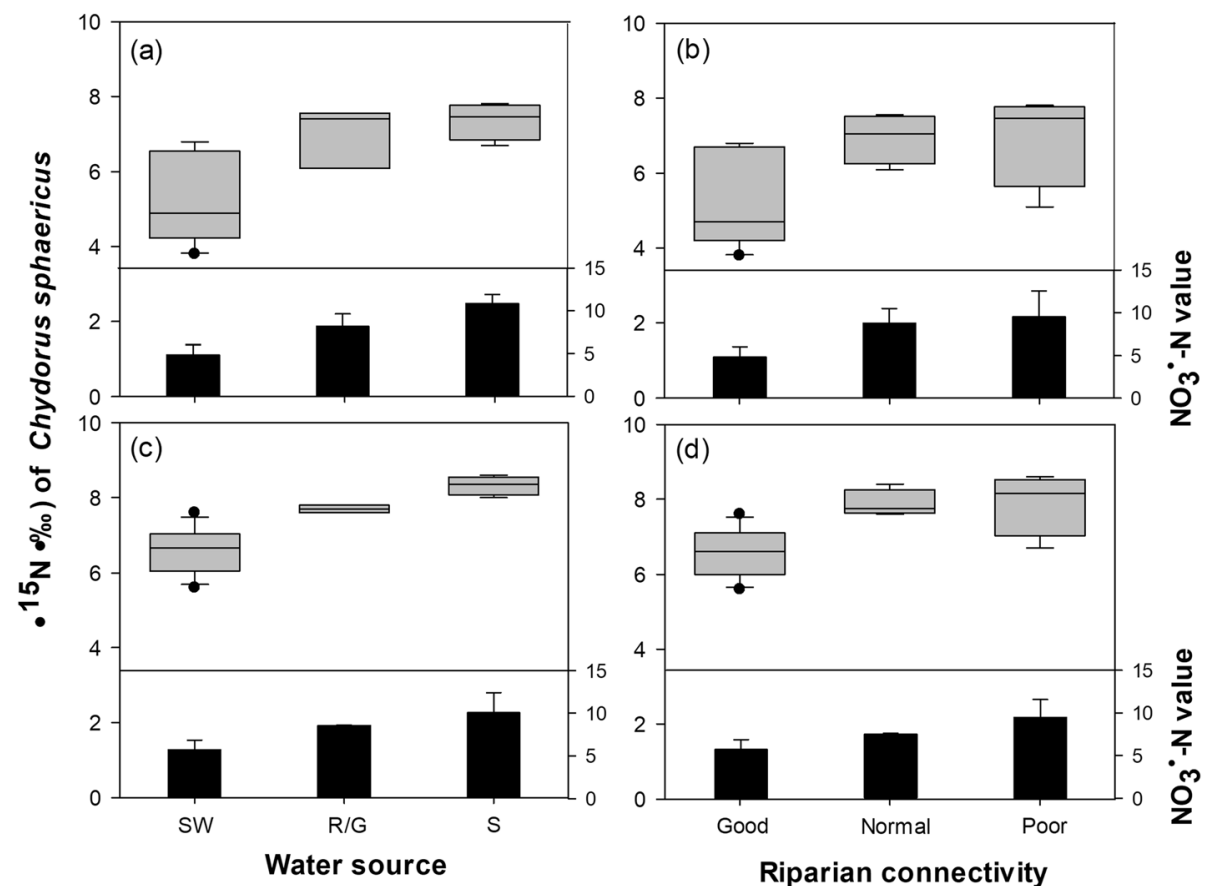

Fig. $2 \delta^{15} \mathrm{~N}(\%)$ of Chydorus sphaericus and $\mathrm{NO}_{3}{ }^{-}$-N levels of each water source (SW, surface water; R/G, rainfall/groundwater; S, sewage) and according to riparian connectivity, respectively, in $\mathbf{a}, \mathbf{b}$ spring and $\mathbf{c}, \mathbf{d}$ autumn. Bars and error bars represent an average of replicates ( \pm SD)

levels in each wetland. In general, phytoplankton absorb the ammonia ion in the DIN pool selectively rather than the nitrate ion, during which the fractionation is 10 $20 \%$ for the ammonia ion, $5-10 \%$ for the nitrate ion, and $1 \%$ for the nitrite ion. The nitrogen isotope ratio of phytoplankton is, therefore, determined using the mass balance of all of these nitrogen sources. Zooplankton, including C. sphaericus, ingest phytoplankton as a food source and are subjected to fractionation of $2-3 \%$ by the effect of the trophic pathway. Thus, the relationship between zooplankton and the nitrate ion of the nitrogen isotope ratio can be established if phytoplankton absorb only nitrate ion in an ammonia-free water environment. However, such conditions rarely occur in wetland and river ecosystems, except in nutrition-depleted oceanic ecosystems in which ammonia is not consumed by phytoplankton in the surface water and nitrate is continuously supplied via upwelling from the deep-sea bottom. In the present study, the positive relationship between $\mathrm{NO}_{3}{ }^{-} \mathrm{N}$ in water and $\delta^{15} \mathrm{~N}$ of C. sphaericus could reflect the environmental changes in the wetlands over a long period of time in a stable condition. Therefore, this relationship can be only applied to elucidate the hydrological characteristics of riverine wetlands

The riverine wetland in the present study was constructed in 2011 as a component of river maintenance efforts; however, the wetland environment and hydrological regime are regularly affected by factors such as sedimentation, structure transformation, and human disturbance. Inlet and outlet deterioration and continuous inflow of sewage accelerate pollutant enrichment in wetlands and influence the growth and distribution of biological factors. Nevertheless, information about wetlands, such as animal distributions and water quality measurements, is rarely collected and few plans have been developed for the systematic management and conservation of such ecosystems. Furthermore, maintenance and budget provisions are not included in business statements for stream implementation projects, making proactive management unfeasible. From this perspective, the nitrate stable isotopes of $C$. sphaericus are comparatively easier and more accessible indicators of wetland water pollution and eutrophication. As a result, the level of nutrient inflow in each wetland can be easily identified by continuously monitoring the nitrate stable isotopes of C. sphaericus, permitting methodical management of water pollution and eutrophication to secure wetland habitat functions. This monitoring system can also be applied to wetlands created near the Geum, Han, and Yeongsan Rivers, as well as in other areas of South Korea.

\section{Conclusions}

The riverine wetland sites in the present study were constructed in 2011 as a component of river improvement efforts, but these sites have consistently been modified by sedimentation, structural transformation, and human disturbance since their construction. We found that the local-scale hydrological conditions of each wetland led to 


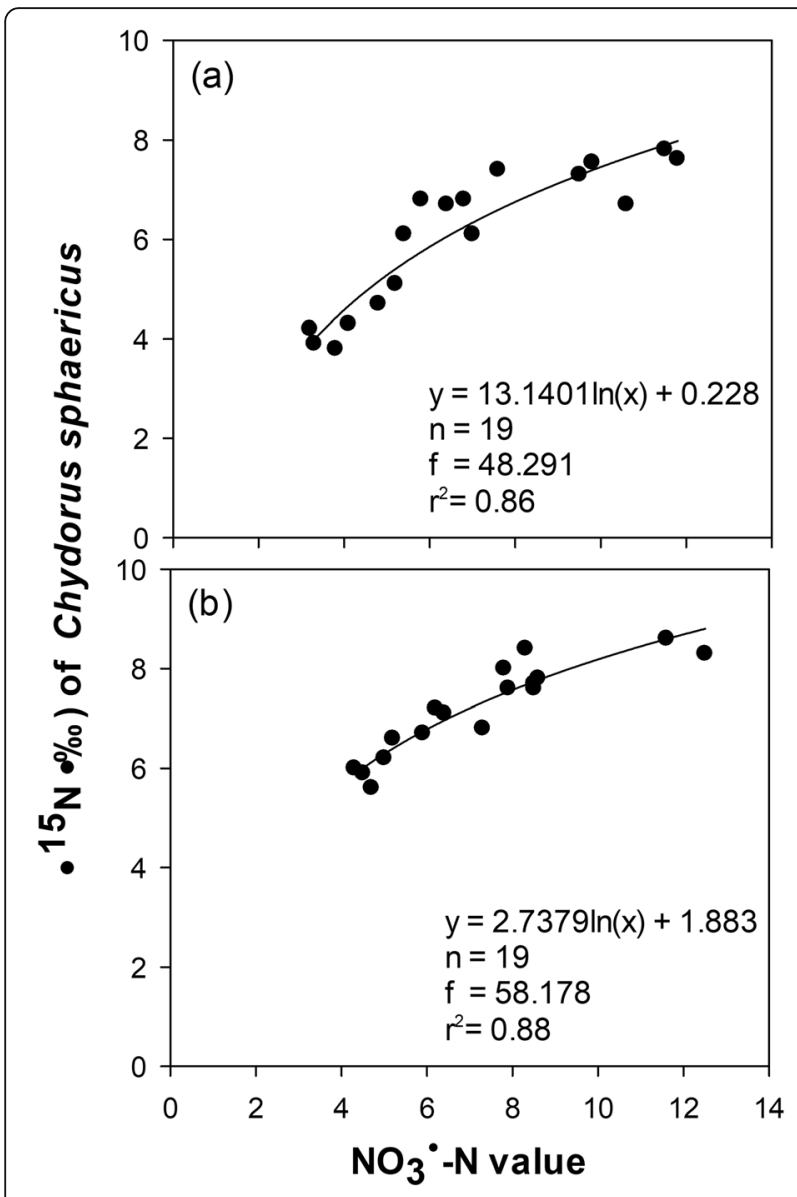

Fig. 3 Relationships between the $\mathrm{NO}_{3}{ }^{-}-\mathrm{N}$ value and $\delta^{15} \mathrm{~N}(\%)$ of Chydorus sphaericus (regression $d f=1$, residual $d f=17$ ) in a spring and $\mathbf{b}$ autumn

different levels of $\mathrm{NO}_{3}{ }^{-}-\mathrm{N}$ and $\delta^{15} \mathrm{~N}$ in C. sphaericus. Channel and riparian type wetlands have strong connections with the main river and tributaries and a high water conveyance efficiency, resulting in low $\mathrm{NO}_{3}{ }^{-} \mathrm{N}$ content. However, the detention ponds fed by sewage inflow or rainfall/groundwater had a higher $\mathrm{NO}_{3}{ }^{-}-\mathrm{N}$ content. Although the nitrate stable isotope measurement of DOM or POM, which directly influences the $\mathrm{NO}_{3}{ }^{-}-\mathrm{N}$, are more effective for monitoring changes, the collection and analysis of these factors are relatively difficult. The different $\mathrm{NO}_{3}{ }^{-}-\mathrm{N}$ contents of each wetland were closely related to $\delta^{15} \mathrm{~N}$ in C. sphaericus, and the regression analyses also revealed a positive correlation between $\delta^{15} \mathrm{~N}$ of $C$. sphaericus and $\mathrm{NO}_{3}{ }^{-}-\mathrm{N}$ content. In addition, $C$. sphaericus has a high biomass and dominates wetlands where aquatic plants are abundant in high density, which makes their collection and analysis convenient. The positive relationship between the $\mathrm{NO}_{3}{ }^{-}-\mathrm{N}$ content in each wetland and $\delta^{15} \mathrm{~N}$ in C. sphaericus indicates that C. sphaericus can be used to elucidate the hydrological characteristics of riverine wetlands (e.g., water quality changes).

\section{Materials and methods}

\section{Site description and hydrological conditions}

The study sites monitored in the riverine wetlands are located in the middle and lower reaches of the Nakdong River. The Nakdong River Basin was heavily modified by the Four Large River Projects, which involved the construction of eight large weirs across the river in 2011 to maintain a minimum channel depth and to facilitate water supply. Furthermore, most riverine areas have been modified for human use, e.g., through the construction of parks, parking lots, and other amenities. Historically, there were numerous riverine wetlands in the river basin, but human activities have led to modifications or losses in their morphologies and habitat structure. A total of 147 artificial wetlands were constructed in four river basins (Ministry of Land, Transport, and Maritime Affairs 2014). We selected 16 riverine wetlands located in the middle and lower areas of the Nakdong River.

The local-scale hydrological characteristics of each wetland were analyzed using a field survey and satellite map (Table 1). Wetlands were classified into three types according to their form and construction purpose: channel, detention pond, or riparian. The channel type was similar to a small stream constructed by retaining the form of a previous stream or furcating it from the main river. Detention ponds were a puddle form, without inlets or outlets. Riparian wetlands were distributed throughout the littoral area in the river channel. Water sources were also classified into three types: surface water, which flowed in from the main river or tributary; sewage, which consisted of contaminated water flowing through a drainage gate; and rainfall/groundwater, which fed wetlands without inflow from the main river or tributaries. Riparian connectivity was used to evaluate the resulting water conveyance efficiency from the main river or tributaries, whereby poor connectivity indicated minimal to nonexistent inlet/outlet functions, good connectivity indicated excellent inlet/outlet functions, and moderate connectivity indicated equivalent inlet and outlet functions. The soil type, topography, edge index, and area of each wetland were measured using a Geographic Information Systems (GIS) program (ArcGIS 10.1; ESRI, Redlands, CA, USA) and a digital map (National Geographic Information Institute 2005; scale 1:25,000).

\section{Collection and stable isotope analysis of Chydorus sphaericus}

For C. sphaericus collection and $\mathrm{NO}_{3}{ }^{-}-\mathrm{N}$ measurement, we randomly selected three sampling points based on virtual grids constructed over the maps of each study site. Water samples $(10 \mathrm{~L})$ were collected at each point for enumeration and stable isotope analysis of $C$. sphaericus in May and October 2017. Water samples of $5 \mathrm{~L}$ were filtered through a $32-\mu \mathrm{m}$ mesh plankton net and the filtrates were 
preserved in sugar formalin with a final formaldehyde concentration of 4\% (Haney and Hall 1973). Chydorus sphaericus individuals were sorted from the remaining $5 \mathrm{~L}$ samples using a micropipette for stable isotope analysis. Identification and enumeration of C. sphaericus was performed using a Zeiss Axioskop 40 (Zeiss, Göttingen, Germany) at $\times 200$ (Mizuno and Takahashi 1999).

Water samples were stored on ice immediately after collection and were filtered at $0.45 \mu \mathrm{m}$ in the laboratory within hours of sampling. The filtered samples were frozen until analysis of $\mathrm{NO}_{3}{ }^{-}-\mathrm{N}$. Nitrate concentrations were analyzed with an Autoanalyzer using cadmium reduction (EPA Method, N87-0065). The lower limit of detection in most cases was $0.025 \mathrm{mg} \mathrm{L}^{-1} \mathrm{~N}$; because samples were often below this limit, a value of 0.0125 $\mathrm{mg} \mathrm{L}^{-1} \mathrm{NO}_{3}{ }^{-}-\mathrm{N}$ was assigned to samples below the limit of detection when averaging the series.

Since acidification has detrimental effects on nitrogen values, stable isotopic samples of $C$. sphaericus were not acidified to remove the inorganic carbonates (Pinnegar and Polunin 1999). All samples were freeze-dried, homogenized with a mortar and pestle, and stored at $-70^{\circ} \mathrm{C}$ prior to analysis. Nitrogen isotope ratios were determined using continuous-flow isotope mass spectrometry. Dried C. sphaericus samples (ca. $1 \mathrm{mg}$ ) were combusted in an elemental analyzer (EuroVector SpA, Milan, Italy) and the resultant $\mathrm{N}_{2}$ gas was injected into an isotope ratio mass spectrometer (CF-IRMS, IsoPrime) in a continuous flow using a helium carrier. Data were expressed as the relative concentration (\%) difference between sample and conventional standards of Pee Dee Belemnite carbonate (PDB) for carbon and air $\mathrm{N}_{2}$ for nitrogen according to the following equation:

$$
\delta^{15} \mathrm{~N}(\%)=\left[\left({ }^{15} \mathrm{~N}:{ }^{14} \mathrm{~N}_{\text {sample }} /{ }^{15} \mathrm{~N}:{ }^{14} \mathrm{~N}_{\text {standard }}\right)-1\right] \times 1000
$$

A secondary standard of known relation to the international standard was used as the reference. Standard deviations of $\delta^{15} \mathrm{~N}$ for analyses with 20 replicates of peptone standard were \pm 0.1 and $\pm 0.2 \%$, respectively.

\section{Data analysis}

We used regression analysis to examine the relationship between nitrate stable isotopes in $C$. sphaericus and $\mathrm{NO}_{3}{ }^{-}{ }^{-} \mathrm{N}$ levels in each study site. We tested the linear, exponential, inverse, power, and logistic functions to determine an equation that generates the best curve fit. The curve-fitting equation that returned the highest determination coefficient was selected to explain the observed relationships. All statistical analyses, including the regression analyses, were conducted using the statistical package SPSS for Windows v. 20.

\section{Abbreviations}

DOM: Dissolved organic matter; GIS: Geographic Information Systems; POM: Particulate organic matter

\section{Acknowledgements \\ This research was fully supported by the Basic Science Research Program through the National Research Foundation of Korea (NRF) funded by the Ministry of Education, South Korea (grant number NRF-2010-0024507; http:// www.nrf.re.kr). The funders had no role in study design, data collection and analysis, decision to publish, or preparation of the manuscript.}

\section{Authors' contributions}

J-YC and S-KK participated in the design of the study, field survey, and data analyses and wrote the manuscript draft. J-CK and G-HL conceived the study, participated in the design of the study, edited the manuscript draft, and secured the funding. All authors read and approved the final manuscript.

\section{Funding}

This research was supported by Basic Science Research Program through the National Research Foundation of Korea (NRF) funded by the Ministry of Education, South Korea (grant number NRF-2010-0024507; http://www.nrf.re. $\mathrm{kr})$.

Availability of data and materials

Datasets generated during and/or analyzed during this study are available from the corresponding author on reasonable request.

Ethics approval and consent to participate

Not applicable

\section{Consent for publication}

Not applicable

Competing interests

The authors declare that they have no competing interests.

Author details

${ }^{1}$ National Institute of Ecology, Seo-Cheon Gun, Chungcheongnam Province 33657, South Korea. ${ }^{2}$ Ecolab GONGSAENG, Suncheon, Jeollanam Province 57905, South Korea.

Received: 7 October 2019 Accepted: 9 December 2019

Published online: 31 December 2019

\section{References}

Alcorlo P, Baltanás A. The trophic ecology of the red swamp crayfish (Procambarus clarkii) in Mediterranean aquatic ecosystems: a stable isotope study. Limnetica. 2013;32(1):121-38.

Ali MM, Mageed AA, Heikal M. Importance of aquatic macrophyte for invertebrate diversity in large subtropical reservoir. Limnologica. 2007; 37(2):155-69.

Choi JY, Kim SK, Jeong KS, Joo GJ. Distribution pattern of epiphytic microcrustaceans in relation to different macrophyte microhabitats in a shallow wetland (Upo wetlands, South Korea). Oceanol Hydrobiol Stud. 2015:44(2):151-63.

Cole JJ, Carpenter SR, Kitchell J, Pace ML, Solomon CT, Weidel B. Strong evidence for terrestrial support of zooplankton in small lakes based on stable isotopes of carbon, nitrogen, and hydrogen. Proc Nati Acad Sci. 2011;108(5):1975-80.

Euliss $\mathrm{NH}$, Mushet DM. Influence of agriculture on aquatic invertebrate communities of temporary wetlands in the prairie pothole region of North Dakota. USA. Wetlands. 1999;19(3):578-83.

Green EK, Galatowitsch SM. Differences in wetland plant community establishment with additions of nitrate- $\mathrm{N}$ and invasive species (Phalaris arundinacea and Typha xglauca). Can J Bot. 2001;79(2):170-8.

Green EK, Galatowitsch SM. Effects of Phalaris arundinacea and nitrate-N addition on the establishment of wetland plant communities. J Appl Ecol. 2002;39(1):134-44.

Haney JF, Hall DJ. Sugar-coated Daphnia: a preservation technique for Cladocera 1. Limnol Oceanogr. 1973;18(2):331-3. 
Heaton THE. Isotopic studies of nitrogen pollution in the hydrosphere and atmosphere: a review. Chem. Geol. Isotope Geosciences Section. 1986;59: 87-102.

Illyová M, Némethová D. Long-term changes in cladoceran assemblages in the Danube floodplain area (Slovak-Hungarian stretch). Limnologica. 2005;35(4): 274-82.

Kattel G, Sirocko F. Palaeocladocerans as indicators of environmental, cultural and archaeological developments in Eifel maar lakes region (West Germany) during the Lateglacial and Holocene periods. Hydrobiologia. 2011;676(1):203.

Kellman LM, Hillaire-Marcel C. Evaluation of nitrogen isotopes as indicators of nitrate contamination sources in an agricultural watershed. Agric Ecosyst Environ. 2003;95(1):87-102.

Kidd KA. Use of stable isotope ratios in freshwater and marine biomagnification studies. Environ Toxicol. 1998:357-76.

Kim KH, Yun ST, Kim HK, Kim JW. Determination of natural backgrounds and thresholds of nitrate in South Korean groundwater using model-based statistical approaches. J Geochem Explor. 2015;148:196-205.

Knight RL, Payne WW Jr, Borer RE, Clarke RA Jr, Pries JH. Constructed wetlands for livestock wastewater management. Ecol Eng. 2000;15(1-2):41-55.

Kovacic DA, David MB, Gentry LE, Starks KM, Cooke RA. Effectiveness of constructed wetlands in reducing nitrogen and phosphorus export from agricultural tile drainage. J Environ Qual. 2000;29(4):1262-74.

Lake JL, McKinney RA, Osterman FA, Pruell RJ, Kiddon J, Ryba SA, Libby AD. Stable nitrogen isotopes as indicators of anthropogenic activities in small freshwater systems. Can J Fish Aquat Sci. 2001;58(5):870-8.

Lee JY, Kim JK, Owen JS, Choi Y, Shin K, Jung S, Kim B. Variation in carbon and nitrogen stable isotopes in POM and zooplankton in a deep reservoir and relationship to hydrological characteristics. J Freshw Ecol. 2013;28(1):47-62.

Lee KS, Bong YS, Lee D, Kim Y, Kim K. Tracing the sources of nitrate in the Han River watershed in Korea, using $\delta^{15} \mathrm{~N}_{-} \mathrm{NO}_{3}{ }^{-}$and $\delta^{18} \mathrm{O}-\mathrm{NO}_{3}{ }^{-}$values. Science of the Total Environment. 2008;395(2-3):117-24.

Ministry of Land, Transport and Maritime Affairs. Report on survey and evaluation of four river project. Seoul; 2014. p. 1-226.

Mizuno T, Takahashi E. An illustration guide to freshwater zooplankton in Japan. Simizu: Tokai Univ; 1999

Peterson BJ, Fry B. Stable isotopes in ecosystem studies. Annu Rev Ecol Syst. 1987;18(1):293-320

Pinnegar JK, Polunin NVC. Differential fractionation of $\delta^{13} \mathrm{C}$ and $\delta^{15} \mathrm{~N}$ among fish tissues: implications for the study of trophic interactions. Funct Ecol. 1999; 13(2):225-31.

Power M, Power G, Caron F, Doucett RR, Guiguer KR. Growth and dietary niche in Salvelinus alpinus and Salvelinus fontinalis as revealed by stable isotope analysis. In: Ecology, behaviour and conservation of the charrs, genus Salvelinus. Dordrecht: Springer; 2002. p. 75-85.

Rybak Jl, Błędzki LA. Freshwater planktonic crustaceans. Warsaw. 2010.

Swanson HK, Johnston TA, Leggett WC, Bodaly RA, Doucett RR, Cunjak RA. Trophic positions and mercury bioaccumulation in rainbow smelt (Osmerus mordax) and native forage fishes in northwestern Ontario lakes. Ecosystems. 2003;6(3):289-99.

Tavernini S. Seasonal and inter-annual zooplankton dynamics in temporary pools with different hydroperiods. Limnologica. 2008;38(1):63-75.

Vijverberg J, Boersma M. Long-term dynamics of small-bodied and large-bodied cladocerans in a shallow reservoir exposed to eutrophication with special attention for Chydorus sphaericus. Hydrobiologia. 1997;360:233-42.

Wantzen KM, Junk WJ. The importance of stream-wetland-systems for biodiversity: a tropical perspective. Biodiversity in wetlands: assessment, function and conservation. 2000;1:11-34

Wayland M, Hobson KA. Stable carbon, nitrogen, and sulfur isotope ratios in riparian food webs on rivers receiving sewage and pulp-mill effluents. Can J Zool. 2001;79(1):5-15.

Wells ER, Krothe NC. Seasonal fluctuation in $\delta^{15} \mathrm{~N}$ of groundwater nitrate in a mantled karst aquifer due to macropore transport of fertilizer-derived nitrate. J Hydrol. 1989;112:191-201.

Woli KP, Nagumo T, Hatano R. Magnitude of nitrogen pollution in stream water due to intensive livestock farming practices. Soil Sci Plant Nut. 2002:48(6):883-7.

\section{Publisher's Note}

Springer Nature remains neutral with regard to jurisdictional claims in published maps and institutional affiliations.

Ready to submit your research? Choose BMC and benefit from:

- fast, convenient online submission

- thorough peer review by experienced researchers in your field

- rapid publication on acceptance

- support for research data, including large and complex data types

- gold Open Access which fosters wider collaboration and increased citations

- maximum visibility for your research: over $100 \mathrm{M}$ website views per year

At BMC, research is always in progress.

Learn more biomedcentral.com/submissions 